\title{
CONSERVADORISMO CONDICIONAL NA DIVULGAÇÃO \\ DE LUCROS EM COMPANHIAS ABERTAS BRASILEIRAS: \\ DIFERENÇAS ENTRE EMISSORAS E NÃO EMISSORAS \\ DE ADR E ENT'RE SISTEMAS CONTÁBEIS
}

\section{CONDITIONAL CONSERVATISM IN REPORTING EARNINGS IN BRAZILIAN PUBLIC COMPANIES: DIFFERENCES BETWEEN ADR ISSUING AND NOT-ISSUING COMPANIES AND BETWEEN ACCOUNTING SYSTEMS}

\author{
ANTONIO CARLOS DIAS COELHO \\ Pós-doutor em Ciências Contábeis pela Faculdade de Economia, Administração e Contabilidade da \\ Universidade de São Paulo (FEA-USP). \\ Professor associado da Faculdade de Economia, Administração, Atuária, Contabilidade e \\ Secretariado Executivo da Universidade Federal do Ceará (UFC). \\ Avenida da Universidade, 2431, Benfica - Fortaleza - CE - Brasil - CEP 60020-180 \\ E-mail: acarloscoelho@terra.com.br
}

\section{JOANILIA NEIDE DE SALES CIA}

Doutora em Administração pela Escola de Administração de Empresas de São Paulo da Fundação Getulio Vargas. Professora da Faculdade de Economia, Administração e Contabilidade da Universidade de São Paulo (FEA-USP). Avenida Professor Luciano Gualberto, 908, Butantã - São Paulo - SP - Brasil - CEP 05508-900

E-mail: joanilia@usp.br

IRAN SIQUEIRA LIMA

Doutor em Ciências Contábeis pela Faculdade de Economia, Administração e Contabilidade da Universidade de São Paulo (FEA-USP). Professor doutor da Faculdade de Economia, Administração e Contabilidade da Universidade de São Paulo. Avenida Professor Luciano Gualberto, 908, Butantã - São Paulo - SP - Brasil - CEP 05508-900 E-mail: iranlima@uol.com.br 


\section{RESUMO}

O artigo examina as diferenças, em termos de qualidade informacional (conservadorismo condicional), das demonstrações contábeis de companhias brasileiras de capital aberto emissoras e não emissoras de ADR. Também são examinadas as demonstrações publicadas nos dois sistemas contábeis (PCAB e USGAAP). As hipóteses propõem que não há diferenças nos graus de conservadorismo condicional entre as firmas em razão das similaridades contratuais e institucionais, da inexistência de incentivos para alterar o comportamento dos gestores pelo processo de cross-listing e da insuficiência de motivação pela aplicação de princípios contábeis diversos. Os modelos de componentes transitórios nos lucros (BASU, I997) e de associação entre apropriações contábeis e fluxos de caixa (BALL; SHIVAKUMAR, 2005) foram utilizados para os testes. Para estimar os coeficientes de associação dos dois modelos, utilizou-se análise de dados em painel. Os resultados confirmaram as hipóteses.

\section{PALAVRAS-CHAVE}

Conservadorismo condicional; Emissão de ADR; Sistemas contábeis; Antecipação assimétrica de perdas; Companhias de capital aberto.

\section{ABSTRACT}

The article examines the differences, in terms of information quality (conditional conservatism), of the accounting reports of Brazilian public companies issuing and not issuing ADR. It is also examined the demonstrations published in the two accounting systems (BRGAAP and USGAAP). The hypotheses consider that there are no differences in the degrees of conditional conservatism among the firms due to: contractual and institutional similarities, the inexistence of incentives to modify managers' behavior by the process of cross-listing, and the lack of motivation by application of different accounting principles. The models of Transitory Earnings 
Components (BASU, 1997) and Association between Accruals and Cash Flows (BALL; SHIVAKUMAR, 2005) were used for the tests. To estimate the association coefficients for the two models, it was used panel data analysis. The results confirmed the hypotheses.

\section{KEYWORDS}

Conditional conservatism; ADR's issuing; Accounting systems; Losses asymmetric anticipation; Public companies.

\section{INTRODUÇÃO}

Ao longo da última década, tem havido, entre as sociedades por ação brasileiras, processo de emissão de American Depositary Receipts (ADR) com o fim de listagem no mercado de capitais americano; atualmente, cerca de 40 firmas brasileiras compõem tal grupo.

No curso da listagem no exterior, as empresas em questão passaram a fornecer informações contábeis no ambiente americano apuradas em sistema contábil diverso ao de suas demonstrações originais; se estas são divulgadas na forma das práticas contábeis adotadas no Brasil (PCAB), aquelas são emitidas segundo os princípios contábeis vigentes nos Estados Unidos (USGAAP).

Embora os lucros apurados sejam certamente diferentes segundo os dois conjuntos de normas, sua eficiência informacional dependerá do ambiente contratual (WATTS, 2003) e dos incentivos econômicos aos gestores para atender a uma efetiva demanda por dados contábeis públicos de qualidade (BALL, 200I).

Considerando que existe uma maior proteção aos investidores no ambiente institucional americano (BLACK, 200I), há expectativa de que as empresas brasileiras listadas nesse ambiente adotem práticas de governança corporativa alinhadas com o sistema jurídico americano, no que tange à qualidade informacional de suas peças contábeis.

Pode-se, entretanto, arguir que o peso inexpressivo das ações brasileiras no montante do mercado americano não enseje níveis de enforcement para que os gestores dessas firmas sejam incentivados para a adoção de atributos de qualidade informacional nas informações contábeis vazadas em USGAAP.

Do mesmo modo, a simples ação de listagem em dois mercados não conduzirá a empresa a adotar práticas diferenciadas de governança corporativa no mercado local, o que implica que as demonstrações domésticas manterão os atri- 
butos de qualidade na forma ditada pelos incentivos econômicos locais à eficiência informacional.

Adotando o atributo do conservadorismo condicional como medida da qualidade informacional de relatórios contábeis, vimos questionar se o processo de cross-listing afeta o grau de antecipação assimétrica de perdas econômicas na apuração dos resultados contábeis das sociedades por ação emissoras de ADR.

Essa questão desdobra-se em comparar o grau de conservadorismo condicional com suas congêneres companhias de capital aberto listadas apenas na Bolsa de Valores de São Paulo (Bovespa), bem como em examinar diferenças na antecipação assimétrica de perdas econômicas nos relatórios emitidos nos dois sistemas contábeis.

A hipótese adotada é de que as empresas consideradas na amostra não apresentam evidências da adoção de conservadorismo condicional, mantendo o comportamento de baixa qualidade informacional detectado em pesquisas anteriores (COELHO, 2007) para o ambiente brasileiro; ademais, a emissão de relatórios contábeis segundo as normas contábeis americanas (USGAAP) não implica a adoção de níveis diferenciados de conservadorismo condicional.

Tal expectativa toma por base o conceito adiante discutido de que a existência de um conjunto de normas não garante, por si só, a qualidade dos números contábeis; esta será sempre função de demanda efetiva por dados contábeis públicos, a qual promove incentivos econômicos para o comportamento dos gestores; por conseguinte, entende-se que a listagem de empresas brasileiras no mercado americano, em si, não fornece tais incentivos aos gestores brasileiros, os quais preferem a forma de governança corporativa imperante no Brasil.

O objetivo da pesquisa é testar o nível de conservadorismo condicional e de reconhecimento antecipado assimétrico de perdas econômicas das firmas brasileiras listadas no mercado americano, comparando os grupos de emissoras e não emissoras de ADR e as demonstrações contábeis do grupo de emissoras de ADR nos dois sistemas contábeis.

\section{REFERENCIAL TEÓRICO}

Explica-se tradicionalmente o conservadorismo pela tendência histórica e universal entre os contadores de seguir a regra informal de "não antecipar o registro de lucros, mas consignar antecipadamente todas as perdas" (BLISS, I924 apud BASU, I997, p. 7); o efeito da prática decorrente de tal máxima é que os ativos tenderão a estar subavaliados e os passivos superavaliados por qualquer métrica contábil que se aplique. 
Os textos contábeis baseados em teorias normativas e a maioria dos princípios contábeis exarados mundialmente tratam o conservadorismo na ótica de lançar valores com parcimônia, sem estabelecer um propósito ou uma lógica que não o costume ou a tradição como justificativa para esse procedimento.

Exemplos desse enfoque podem ser encontrados em textos brasileiros (IUDÍCIBUS, 2004) ou em conceitos oficiais americanos (SFAC 2) que expressam: “[...] se duas estimativas de valores a receber ou a pagar são igualmente prováveis, o conservadorismo impõe o uso da estimativa menos otimista" (BASU, I997, p. 7).

Sua aplicação se dá na prática pela utilização do custo histórico como base de valor, pelo não reconhecimento de ativos intangíveis, por não adotar o registro de opções de crescimento ditadas por favoráveis condições de investimento ainda não aproveitadas ou ainda pela existência de quase renda e de possíveis sinergias associadas a ativos não reconhecidos.

Fica claro que a prática de conservadorismo na apuração dos resultados também conduz a menores valores de patrimônio líquido divulgados, pela acumulação de resultados que já antecipam possíveis perdas futuras.

Basu (I997), sob a hipótese de motivações diferenciadas para firmas e gerentes, define conservadorismo como a tendência dos contadores em exigir uma maior verificação para reconhecer perspectivas positivas (good news) que para registrar prováveis perdas (bad news). Por consequência, espera-se que os lucros publicados reflitam perdas econômicas mais tempestivamente que ganhos econômicos, em razão da assimetria de tratamento dado à verificabilidade requerida para o registro antecipado dos dois tipos de fenômeno.

Ball e Shivakumar (2005) adotam essa mesma definição, separando os conceitos de conservadorismo condicional, referindo-se ao fenômeno que enfatiza a associação entre a antecipação do registro e a possibilidade de perdas econômicas, do processo que incondicionalmente divulga baixos valores de patrimônio líquido, independentemente de sinais de prováveis perdas econômicas.

Ao abordar a motivação econômica para o fenômeno do conservadorismo condicional, Basu (I997) registra que este já foi detectado no século XVIII, com referências à regra do custo ou mercado, o menor. Esse autor descarta, assim, que a origem desse fenômeno esteja associada à tributação de renda, a litígios de investidores ou à regulação contábil, instituições posteriores àquela data.

Basu (I997) concorda com a motivação contratual como origem para o reconhecimento assimétrico de perdas econômicas, assinalando que tributos, custos de litígio, processo político e forças regulatórias têm influenciado muito mais o nível de conservadorismo na contabilidade.

Watts (2003) estende a discussão do conservadorismo entendido como a necessidade assimétrica de maior verificabilidade para a antecipação do registro de ganhos econômicos, arguindo a dificuldade em registrar lucros não realiza- 
dos sobre os quais não há ainda direitos legais. A dependência de sua ocorrência será completamente exógena à empresa e dependente de clientes, concorrência e regras econômicas futuras.

Argumenta esse autor que a verificabilidade assimétrica é extremamente relevante porque dela dependerá o uso de números contábeis em contratos executáveis judicialmente, e a antecipação de ganhos favoreceria apenas os gerentes ou acionistas majoritários. Nesse caso, mesmo os acionistas minoritários optariam pela prática do conservadorismo condicional, uma vez que tal atributo implicaria preservar seus direitos no momento atual.

O registro de ganhos prováveis nos números contábeis apenas teria sentido se contribuísse para efeitos contratuais, contudo seu uso não seria eficiente, pois não se teria como demonstrar em tribunais a eficácia de ganhos ainda não recebidos; não há como garantir incrementos de receita decorrentes da inovação de produtos ou da tomada de mercados ou da introdução de tecnologias, entretanto será acreditável o aprovisionamento por prováveis perdas decorrentes da entrada de competidores, sendo desejável para contratantes que se antecipe esse fato por métodos de estimação observáveis.

Watts (2003) explica o conservadorismo condicional na ótica de eficiente instrumento contratual, enfatizando que tal procedimento reduz a probabilidade de que o valor dos ativos líquidos ou dos lucros acumulados esteja sobrestimado em qualquer momento do tempo; impede-se, ceteris paribus, a probabilidade de ocorrência de distribuições de resultados que violem contratos ou impactem o valor da firma.

$\mathrm{Na}$ perspectiva informacional, esse autor destaca que valores conservadores de liquidação ordenada dos ativos líquidos da empresa são relevantes para os investidores em ações por causa da opção de abandonar o investimento, seja pela saída da posição acionária, seja pela saída ordenada do negócio vendendo ativos específicos ou divisões da companhia.

Em suma, os atributos da mensuração contábil relacionados ao motivo comentado de uso da contabilidade como mecanismo de contratação eficiente são:

a) Antecipação tempestiva no reconhecimento de impactos econômicos nos valores dos ativos líquidos;

b) Verificabilidade desses reconhecimentos por instâncias independentes;

c) Assimetria na verificabilidade de ganhos e perdas, exigindo os ganhos maior grau de observabilidade para seu reconhecimento.

O mesmo autor ainda apresenta os custos de litígio em torno de lucros reportados não realizados no futuro como influenciadores da decisão da gerência em adotar a antecipação assimétrica das perdas. 
Ball (200I), por sua vez, atrela a questão da qualidade dos lucros reportados, como informação pública disponibilizada para os agentes econômicos, à eficiência econômica com que eles promovam a redução da assimetria informacional entre os gestores e as partes contratantes das empresas, especialmente acionistas e investidores.

Entende que a qualidade dos demonstrativos contábeis é função da perspectiva institucional da economia, na medida em que a redução da assimetria informacional é necessária (embora não suficiente) para promover o desenvolvimento de corporações públicas e mercados de capitais economicamente eficientes.

Os principais requerimentos para que lucros publicados sejam informacionalmente eficientes e com atributos de qualidade referem-se à motivação e aos incentivos econômicos criados para que gerentes e auditores gerenciem em seu proveito ou de terceiros os resultados divulgados.

Esse autor defende ainda que o estabelecimento de novos padrões contábeis ou alterações de regulação não surtirá efeito se não for acompanhado de efetivos incentivos e garantias de cumprimento para os gestores, exemplificando com a institucionalização de direitos claros de litígio e legislação que proteja os direitos dos contratantes. O simples risco de incorrer em custos efetivos por não reportar lucros com transparência motivaria os gerentes e auditores a fazê-lo.

Essa assertiva deriva da constatação de que a contabilidade complementa os sistemas institucional e econômico de um país, sendo sua implementação produto de transformações no sistema institucional e legal do país, condições estas exógenas à empresa e ao aparato burocrático contábil.

A demanda por informação pública, independente e verificável, utilizável em litígios por partes presumivelmente prejudicadas decorre da característica da firma de ser intermediária contratual entre proprietários e consumidores.

Essa estrutura contratual determina a demanda por informações públicas e confiáveis: contratação eficiente com a firma pelos detentores de direitos residuais interessados em limitar sua exposição à expropriação de ativos e em avaliar as remunerações dos outros agentes.

A firma concordará em incorrer em custos para o fornecimento de tais informações recebendo em troca melhores termos nos preços de seus insumos e na avaliação de seus produtos. Todavia, se essa troca não for vantajosa para a empresa, esta optará por fornecer informações de forma privada apenas a um grupo de agentes próximos de sua gerência.

As condições para que isso ocorra serão dadas pelo estamento institucional do país. Estruturas de favorecimento de classes, de subsídios e incentivos, de baixo enforcement, de concentração de propriedade, de sistema legal lento e dependente apenas do setor político favorecem a existência de contratos privados. 
Dada essa demanda tão heterogênea, o autor conclui por dois critérios que garantiriam a utilidade e a eficiência econômica da publicação de informações contábeis transparentes:

a) Apuração de lucro com independência em relação ao gestor;

b) Incorporação tempestiva de perdas econômicas ao lucro.

A percepção de lucros corretamente apurados reduz riscos para contratantes, emprestadores e investidores, e só ocorrerá se houver evidência de que os resultados estão apurados de forma independente em relação aos grupos de interesse da firma. A incorporação de resultados econômicos que dependem do conhecimento do negócio pelo gerente coloca em jogo sua credibilidade, a não ser pela verificação por auditores independentes.

O enforcement para tal comportamento de redução de assimetria informacional depende de eficientes sistemas de incentivos privados (planos de compensação eficientemente desenhados) e públicos (efetividade do sistema judicial em garantir direitos de litígio).

O segundo critério para a eficiência das informações contábeis publicadas diz respeito ao conservadorismo e, de certa forma, contrasta com o critério anteriormente discutido, uma vez que propugna por introduzir nos números publicados avaliações assimétricas de futuros impactos negativos no fluxo de caixa da empresa, pela experiência dos gestores.

Ball (200I) argumenta que esse procedimento está alinhado com a visão contratual da firma e contribui para a eficiência das contratações associadas à firma; o incremento da eficiência contratual de tal procedimento decorre da redução da assimetria informacional entre os gestores e os demais contratantes da firma, já que o reconhecimento da expectativa de perdas econômicas estará intrinsecamente associado a julgamentos e avaliações do próprio gerente, pois observável apenas por ele.

O interesse dos fornecedores de capital próprio no reconhecimento assimétrico de perdas econômicas tem duas raízes, uma informacional e a outra de governança corporativa.

Do ponto de vista de governança corporativa, a imposição de procedimentos contábeis de reconhecimento da expectativa de perdas econômicas será demandada como um eficiente mecanismo interno de governança corporativa, na medida em que essa sistemática implica apropriar no momento presente o valor capitalizado de projetos com VPL negativo.

Os benefícios esperados para a firma e para os acionistas estão associados à criação de valor para estes, em função da redução do custo de capital próprio, pois a visualização do risco da empresa será reduzida pelo encurtamento da assimetria informacional entre a gerência e os acionistas. 
Os custos de agência serão governados de forma mais eficiente em qualquer dos estilos de gerência discutidos com o uso do conceito de conservadorismo na apuração do lucro contábil, já que essa prática aproxima os conceitos de lucro contábil e lucro econômico.

Bushman e Piotroski (2006) destacam que não identificam uma teoria que explique as forças econômicas subjacentes à prática do conservadorismo e que estabeleça predições sobre as condições em que tais mecanismos poderiam ser usados.

Especulam, entretanto, que os procedimentos de reconhecer ganhos e perdas carecem de algumas qualidades institucionais, exógenas à decisão gerencial, para que ocorram, quais sejam:

a) Responsabilidades limitadas dos contratantes, significando que haja necessidade de conhecer antecipadamente seus níveis de exposição ao risco;

b) Informações verificáveis e observáveis para serem aceitas em contratos;

c) Sistema de tribunais capaz de coagir à análise de tal observabilidade;

d) Liberdade de litígio e garantia de execução de decisões judiciais para os contratantes, principalmente na legislação vinculada aos mercados de capitais;

e) Separação de gestão, propriedade e controle das firmas, acompanhada de mecanismos eficientes de governança corporativa;

f) Reconhecimento da eficiência econômica da dispersão da propriedade como instrumento de desenvolvimento de formas mais eficazes de contratação;

g) Institutos políticos abertos e direitos de propriedade respeitados.

A vinculação conceitual estabelecida pelos autores baseia-se no fato de que tais atributos provocariam demanda contratual e litigiosa por números contábeis verificáveis e parcimoniosos, que não induzam à tomada de decisões prejudiciais aos agentes econômicos.

Pressupõem que sociedades que tendem a demandar maior conservadorismo nos números contábeis publicados que as demais apresentam:

a) Estrutura de propriedade dispersa;

b) Legislação econômica de proteção a direitos dos investidores;

c) Sistema jurídico independente e capaz de fazer executar decisões;

d) Instituições políticas de respeito ao direito de propriedade.

Os resultados da pesquisa aceitam as hipóteses estabelecidas, utilizando como proxy para essas características institucionais indicadores desenvolvidos em pesquisas financeiras do gênero, além da origem jurídica do país como code law ou common law. 
Concluem que a simples utilização de contratos na economia não forma demanda bastante para influenciar no uso do conservadorismo. Seria necessário que existissem sistemas judiciais de alta qualidade, uso acentuado de financiamento por instrumentos públicos (mercado de capitais e títulos de dívida privada) e estruturas difusas de propriedade das firmas para a explicação da prática do conservadorismo, o que se corrobora na pesquisa.

Seguindo esse raciocínio, a linha de pesquisa iniciada por Bushman, Piotroski e Smith (2004) sugere que a prática contábil reage diferentemente a ambientes contratuais diversos, definidos estes ambientes em termos de países segundo a origem de seu sistema jurídico: o direito codificado ou o direito consuetudinário.

Ball, Robin e Wu (2000) especulam que a simples emissão de regras, de padrões e de normas não é bastante para harmonizar os métodos e as escolhas contábeis de gerentes e contadores num dado país; ao contrário, os gerentes responderão invariavelmente a incentivos econômicos para tais escolhas.

O estudo desses autores foi realizado na China, onde, após reformas econômicas, implementaram-se normas contábeis com base nos preceitos do código do International Accounting Standards (IAS), com a criação do código de Accounting Standards for Business Enterprises (Asbe), guardando algumas peculiaridades da realidade chinesa.

Tal regulamentação, utilizada em demonstrações domésticas, não se mostrou suficiente para atender à demanda internacional por informações de empresas listadas querendo atrair capitais estrangeiros.

A pesquisa então pergunta se a elaboração de demonstrações na forma do IAS, certificadas por auditoria efetuada por firmas internacionais, produz relatórios de maior qualidade que aqueles produzidos internamente, no que respeita aos atributos de reconhecimento antecipado de perdas econômicas.

Os resultados, após a estimativa do conservadorismo condicional na forma definida por Basu (I997), tanto para os relatórios emitidos com base nas regras Asbe quanto para aqueles reportados pelos padrões IAS, por empresas listadas na Bolsa chinesa referentes ao período de 1992 a I998, podem ser assim resumidos:

a) Os coeficientes estimados não apontam para reconhecimento assimétrico de perdas econômicas em qualquer dos regimes de apuração;

b) Os resultados apontam para um maior conservadorismo nos números publicados na forma doméstica, refletindo mais um conservadorismo incondicional nos números patrimoniais, isto é, são mais conservadores para a apreensão de más e boas novas que aqueles baseados no IAS;

c) Isso é constatado apesar de os normativos internacionais implicitamente recomendarem a apropriação conservadora de perdas econômicas verificáveis. 
Concluem os autores que a simples transposição de normas mais modernas ou mais amplamente utilizadas não será implementada a não ser que se processem mudanças institucionais nas economias emergentes que impliquem delinear uma efetiva demanda por funções econômicas dos relatórios contábeis, apoiada em leis de proteção a investidores e em garantias de execução de decisões judiciais e de arbitragem.

Um dos estudos pioneiros em avaliar as diferenças internacionais de práticas contábeis (BALL; KOTHARI; ROBIN, 2000) associa tais distinções por meio do grau de antecipação do registro dos efeitos econômicos nos lucros contábeis e do nível de assimetria em que isso é feito, antecipando mais rapidamente as perdas econômicas.

Ball, Kothari e Robin (2000) sugerem que as práticas diversas se devem menos a diferenças nos padrões contábeis diferentes entre países e mais ao tipo de demanda por dados contábeis pelos usuários desses dados, a qual é determinada, ainda segundo o estudo, pelos modelos de governança corporativa característicos dos países de origem jurídica na lei codificada (voltada para o conceito de stakeholder) e dos países de origem jurídica na lei comum (voltada para o conceito de stockholder).

Enquanto o primeiro modelo associa o lucro contábil à remuneração direta de empregados, gerentes, acionistas e governo - os quais são definidos basicamente por informações privadas -, não se preocupando em antecipar assimetricamente o registro de perdas econômicas, o segundo modelo é incentivado por demanda pública de informações associada à regulação, à tributação e a litígios, o que impacta na produção de valores conservadores para os lucros contábeis.

Assim, a pesquisa utiliza o modelo de mercado de Basu (1997) para analisar os resultados publicados e o retorno de mercado de empresas em sete países durante o período de I985 a I995. As conclusões ratificam as hipóteses esboçadas pelos pesquisadores, quais sejam:

a) Importantes propriedades do lucro contábil (mais especificamente o conservadorismo) são função, ao redor do mundo, de variadas demandas a serem satisfeitas sob diferentes arranjos institucionais;

b) O conservadorismo, medido pelo modelo aplicado, se apresenta mais fortemente nas economias que funcionam sob a égide do direito consuetudinário, refletindo a maior proteção a investidores públicos e a operações por meio de mercado nesses países.

Por fim, os autores ressaltam que o estudo de diferenças internacionais nas propriedades dos relatórios contábeis, como determinadas por estruturas institucionais diversas, tem vantagens em relação a analisá-las na ótica de variações nos padrões internacionais porque: 
I. Muitas das práticas contábeis não são decorrentes dos padrões contábeis, uma vez que:

a) A prática é mais detalhada que os padrões;

b) Os padrões são inovados/definidos com defasagem em relação à prática;

c) As firmas não programam os padrões de forma invariável.

2. A extensão em que a prática é determinada por padrões formais é diferente entre países, e o incentivo para o atendimento de tais padrões depende do grau de penalidades e da garantia de sua aplicação.

3. Estudar somente o padrão pode elidir a descoberta de práticas não previstas ou esperadas.

4. Os lucros reportados são influenciados pelas decisões (oportunistas ou eficientes) operacionais e financeiras dos gerentes, dependendo inclusive do tipo de gerência e de incentivos a estes.

Nessa mesma linha de raciocínio, Ball, Robin e Wu (2003) demonstram, com base em evidências empíricas de quatro países asiáticos, que a interação entre padrões contábeis e incentivos a gerentes e auditores pode levar os relatórios contábeis a apresentar atributos não esperados nas definições normativas e a ter níveis de qualidade diferentes dos esperados pelos padrões.

A amostra pesquisada inclui firmas - no período de I984 a I996 - de países asiáticos cujos padrões contábeis foram implementados com base em congêneres lastreados em estrutura de direito comum, levando à hipótese de que essas entidades se comportariam no que toca ao reconhecimento de perdas econômicas nas suas demonstrações, com altos graus de antecipação assimétrica de registro de tais perdas.

As conclusões, contudo, apontam para níveis de conservadorismo similares aos de países com direito codificado, atribuindo os autores tais evidências à estrutura institucional e política dos países, onde os níveis de enforcement são menores que nos países ocidentais de tradição consuetudinária.

Assim, os incentivos econômicos a gerentes, contadores e auditores definem a qualidade dos números contábeis publicados, que se apresenta como efeito endógeno das demandas dos mercados e das influências políticas que são específicos a cada país; tanto que os resultados indicam diferenças nos padrões de qualidade de suas demonstrações contábeis, mensurados pelo grau de conservadorismo condicional estimado.

Os autores concluem apresentando algumas implicações do estudo, quais sejam:

a) Classificar países em termos de seus padrões contábeis pode ser incompleto e enganoso, se não se considerarem as influências institucionais, legais e políticas de seu ambiente contratual; 
b) Países interessados em alcançar maiores indicadores de qualidade de seus relatórios contábeis serão mais efetivos se aplicarem mudanças institucionais e legais aos incentivos a gerentes e auditores, e não importarem padrões estrangeiros, mesmo que de maior qualidade;

c) As diferenças internacionais em reportar lucros contábeis limitam, intrinsecamente, a comparabilidade de informações contábeis por meio apenas da homogeneização de padrões contábeis.

Leuz, Nanda e Wysocki (2003) propõem análise de níveis de gerenciamento de resultados por meio de modelos de apropriações contábeis, em que criam índices de gerenciamento de resultados, por meio de amostra de 8.000 firmas entre o período de I990 a I999, que serão comparados com as características institucionais de $3 \mathrm{I}$ países.

Num primeiro estágio, estabelecem conglomerados segundo as características institucionais e jurídicas dos países, criando três conglomerados classificados como tendo aspectos de economia aberta, intermediária e de economia fechada, de acordo com variáveis que tratam desde nível de concentração de propriedade até indicadores de corrupção.

A associação entre esses conglomerados e os índices de gerenciamento de resultados nos demonstrativos publicados é estatisticamente significante, sendo menores nos países classificados como de economia aberta com vasta proteção a investidores, maior número de empresas de capital aberto e alto índice de disclosure. Os índices chegam a dobrar de valor nos países classificados como de economia fechada.

Os autores proveem explicação baseada nos incentivos para que gestores e controladores adquiram benefícios privados pelo controle, sendo tais incentivos desencorajados na presença de proteção legal a minoritários. Para desviarem recursos para seus próprios interesses, os controladores necessitam gerenciar os resultados de modo que os números contábeis encubram as manobras de desvio.

Assim, as evidências do estudo mostram que a prática de gerenciamento de resultados é negativamente associada com a qualidade da proteção aos direitos de minoritários e do grau de enforcement legal. Ressaltam também uma importante ligação entre a proteção ao investidor e a qualidade dos lucros contábeis reportados aos participantes dos mercados.

$\mathrm{Na}$ mesma linha de pesquisa envolvendo conservadorismo e diferenças institucionais entre economias nacionais, relaciona-se o estudo de Huijgen e Lubberink (2003) que analisa amostra de empresas britânicas no período de I993 a 2002, listadas simultaneamente em bolsas de valores na Inglaterra e nos Estados Unidos. 
Esses autores buscavam evidências, aplicando o modelo de lucro/retorno de Basu (I997), de diferenças no grau de conservadorismo empregado pelas empresas, seja em relação aos seus balanços atendendo às normas britânicas e americanas, seja em relação a empresas não registradas nas bolsas americanas.

Destacam os autores as seguintes evidências:

a) Apesar da semelhança das normas contábeis nos dois países no que respeita a conservadorismo, as empresas listadas em bolsas americanas apresentam maior grau de conservadorismo que aquelas operando apenas na Inglaterra; contudo, as demonstrações daquele grupo não se diferenciam nos resultados apresentados nos Estados Unidos e na Inglaterra;

b) Esse comportamento é atribuído pelos autores ao fato de os gerentes visualizarem maior risco de litígio nos Estados Unidos, onde os investidores têm uma maior preocupação com o conservadorismo, e quererem assumir maior comprometimento (bonding) em busca de prestígio, credibilidade e confiança.

Os mesmos autores (LUBBERINK; HUIJGEN, 2005) investigaram o grau de conservadorismo entre empresas estrangeiras listadas no nível ADR III (às quais se permite captar recursos no mercado americano) e outras classificadas no nível ADR II (não habilitadas a levantar capital nesse mercado); a amostra abrange o período de 1995 a 2004 e também utiliza o modelo de mercado de Basu (1997).

A pesquisa evidencia que as empresas do primeiro tipo apresentam maiores indícios de prática do conservadorismo condicional, deixando espaço para duas conclusões:

a) As empresas interessadas em realizar emissões tendem a fornecer informações mais verificáveis e acreditáveis, de modo que financiem publicamente suas possibilidades de crescimento futuro;

b) Pode-se questionar a ideia de que a demanda por redução de assimetria informacional deriva basicamente do mercado de títulos de dívida, aplicando-se também ao mercado de ações.

De outra parte, reportamos outros estudos realizados sobre diferentes graus de conservadorismo condicional em função de ambientes institucionais distintos:

a) Pope e Walker (I999) encontraram evidências de diferenças do grau de conservadorismo entre países, detectando maior grau de conservadorismo em países com origem jurídica no common law; 
b) García-Lara e Mora (2004) avaliaram a presença de conservadorismo presente no patrimônio líquido e nos lucros entre países europeus, constatando a presença de conservadorismo condicionado a más notícias (bad news).

No Brasil, foi realizada pesquisa relacionada com as métricas de conservadorismo condicional e reconhecimento assimétrico de perdas (COELHO, 2007), não sendo constatada a presença de tal atributo nos lucros publicados pelas sociedades por ação brasileiras.

Santos (2006), por sua vez, realizou estudo em que compara o grau de conservadorismo - mensurado na forma de Basu (I997) - presente nos relatórios contábeis de empresas brasileiras, com ações negociadas nos mercados brasileiro e norte-americano, em suas versões publicadas segundo os padrões dos USGAAP e as regras dos Brgaap, entre i999 e 2004.

As hipóteses de maior presença de conservadorismo e de maior aderência entre retornos e lucros contábeis nos relatórios elaborados sob USGAAP não se confirmam; implicitamente se depreende também que o grau de conservadorismo na amostra de empresas brasileiras não é elevado ou significante, concluindo o autor com explicações calcadas em governança corporativa para os resultados, salientando que o processo de listagem nos Estados Unidos, por si só, não garante a presença dos atributos testados.

Lopes e Tukamoto (2007) também examinam diferenças na qualidade dos relatórios contábeis de empresas brasileiras cross-listed ${ }^{\mathrm{I}}$, publicados segundo os dois sistemas contábeis (USGAAP e $\mathrm{PCAB}^{2}$ ); a metodologia utilizada verifica diferenças de gerenciamento de resultados nos dois conjuntos de relatórios contábeis, segundo várias métricas de tal prática; as conclusões apontam para evidências de que os níveis de gerenciamento de resultados são similares nos dois sistemas contábeis.

Mais recentemente, Santos, Cia e Cia (2007) compararam o grau de conservadorismo entre os resultados contábeis das empresas brasileiras emissoras de ADR, utilizando a metodologia do índice de conservadorismo de Gray, concluindo pela inexistência de diferenças estatisticamente significantes entre os resultados apresentados nos dois sistemas contábeis (USGAAP x normas brasileiras). Utilizando metodologia similar, Lemes, Carvalho e Lopes (2007) concluíram por maior grau de conservadorismo nas demonstrações publicadas segundo as normas de USGAAP, embora sem especificação estatística mais robusta. 


\section{METODOLOGIA}

Os objetivos da pesquisa estão alinhados com os estudos anteriormente relatados, de avaliar se a listagem de companhias abertas brasileiras por meio da emissão de ADR em mercados de capitais estruturados quanto à proteção aos investidores induz seus gestores à eficiência informacional nas peças contábeis publicadas.

O estudo também busca examinar se a edição de demonstrações contábeis sob a égide de conjuntos distintos de normas contábeis (USGAAP e PCAB) influencia a qualidade, em termos do atributo do conservadorismo condicional, dos lucros publicados, no caso das companhias de capital aberto brasileiras listadas em bolsas americanas.

Entendendo que a busca da redução de assimetrias informacionais entre gestores e stakeholders (principalmente investidores do mercado de capitais e acionistas minoritários) decorre do ambiente institucional do país, surge a formulação da questão da pesquisa. Indaga-se se o processo de cross-listing em ambiente com incentivos institucionais e econômicos que estimulam a produção de demonstrações contábeis com qualidade e se a publicação de demonstrações segundo padrões contábeis americanos serão suficientes para gerar a divulgação de números contábeis com eficiência informacional.

As hipóteses a serem testadas baseiam-se na ideia de que a demanda por dados públicos é que induz ao fornecimento de informações que reduzam a assimetria informacional entre os públicos das firmas, ao criar incentivos econômicos para tanto.

Com o processo de cross-listing e a publicação de demonstrações contábeis em USGAAP, espera-se que as firmas adotem melhores práticas de governança corporativa, e assim testam-se as seguintes hipóteses nulas:

- $\mathrm{H}_{\mathrm{OA}}$ : Os lucros reportados pelas companhias abertas emissoras de ADR, assim como aqueles divulgados pelas demais companhias abertas brasileiras, não contêm o atributo do conservadorismo condicional, dado pela antecipação assimétrica tempestiva de perdas econômicas.

- $\mathrm{H}_{\mathrm{OB}}$ : Não há diferenças nos níveis de antecipação assimétrica de perdas econômicas nos relatórios contábeis das companhias abertas brasileiras emissoras de ADR gerados pelos distintos conjuntos de regras contábeis: PCAB e USGAAP.

Os testes serão realizados por meio dos modelos de componentes transitórios nos lucros (BASU, I997) e de associação de apropriações contábeis com fluxos de caixa (BALL; SHIVAKUMAR, 2005). 


\section{MODELO I}

COMPONENTES TRANSITÓRIOS NOS LUCROS

$\begin{aligned} \Delta L U C_{t}= & \alpha_{\circ}+\alpha_{\mathrm{I}} D \Delta L U C_{t-\mathrm{I}}+\alpha_{2} \Delta L U C_{t-\mathrm{I}}+ \\ & \alpha_{3} D \Delta L U C_{t-\mathrm{I}} * \Delta L U C_{t-\mathrm{I}}+\alpha_{4} D G C+ \\ & \alpha_{5} D G C^{*} D \Delta L U C_{t-\mathrm{I}}+\alpha_{6} D G C^{*} \Delta L U C_{t-\mathrm{I}}+ \\ & \alpha_{7} D G C^{*} D \Delta L U C_{t-\mathrm{I}} * \Delta L U C_{t-\mathrm{I}}+\varepsilon_{t} \\ \text { Onde: } & \\ \Delta L U C_{t}= & \text { Variação do lucro no período t; } \\ \Delta L U C_{t-\mathrm{I}}= & \text { Variação do lucro no período t-I; } \\ D \Delta L U C_{t-\mathrm{I}}= & \text { Variável binária: I para variações negativas do lucro } \\ & \text { antecedente e o para variações positivas; } \\ D \Delta L U C_{t-\mathrm{I}} * \Delta L U C_{t-\mathrm{I}}= & \text { Variável de interação de variações negativas do lucro; } \\ D G C= & \text { Variável binária assumindo I para empresas comuns listadas } \\ & \text { na BOVESPA e o para companhias que emitiram ADR; } \\ D G C^{*} D \Delta L U C_{t-\mathrm{I}}^{*} \Delta L U C_{t-\mathrm{I}}= & \text { Variável de interação para variações negativas das } \\ & \text { empresas listadas na BOVESPA; } \\ D G C^{*} D \Delta L U C_{t-\mathrm{I}} ; D G C^{*} \Delta L U C_{t-\mathrm{I}}= & \text { Variáveis captadoras de impactos no intercepto do modelo; } \\ \alpha_{\mathrm{I}} a \alpha_{7}= & \text { Coeficientes do modelo; } \\ \varepsilon_{t}= & \text { Termo de erro do modelo; }\end{aligned}$

Fonte: Ball e Shivakumar (2005).

No modelo I, espera-se que os coeficientes associados a variações negativas dos lucros antecedentes tenham sinal negativo, indicando reversão dessa sinalização no lucro contemporâneo, pois o componente negativo terá sido dado pela antecipação tempestiva de perdas econômicas. Ao contrário, em variações positivas dos lucros, não se espera reversão de sinais, pois não se antecipam ganhos econômicos. Então, os coeficientes dessas variáveis deverão ter sinais positivos.

No Quadro I, descreve-se o comportamento esperado e interpretam-se os coeficientes relativos às variáveis independentes desse modelo. É importante notar que há parâmetros referentes à diferenciação entre os sinais das variações dos lucros e entre os grupos diferentes de empresas. 


\section{QUADRO I}

\section{DESCRIÇÃO DOS PARÂMETROS DO MODELO I}

\begin{tabular}{|c|c|c|c|}
\hline PARÂMETRO & $\begin{array}{l}\text { ASSOCIAÇÃO ENTRE } \\
\text { VARIÁVEIS }\end{array}$ & $\begin{array}{l}\text { ESTADO DA VARIÁVEL } \\
\text { INDEPENDENTE }\end{array}$ & $\begin{array}{l}\text { RESULTADO } \\
\text { ESPERADO }\end{array}$ \\
\hline$\alpha 2$ & $\begin{array}{l}\text { Persistência na série } \\
\text { temporal de lucros }\end{array}$ & $\begin{array}{l}\text { Variações positivas no lucro } \\
\text { antecedente nas emissoras } \\
\text { de ADR }\end{array}$ & $\begin{array}{l}\text { Associação } \\
\text { positiva indicando } \\
\text { persistência }\end{array}$ \\
\hline$\alpha 3$ & $\begin{array}{l}\text { Diferenciação decorrente } \\
\text { do tipo de variação do } \\
\text { lucro }\end{array}$ & $\begin{array}{l}\text { Variações negativas no lucro } \\
\text { antecedente nas emissoras } \\
\text { de ADR }\end{array}$ & $\begin{array}{l}\text { Coeficiente }<0 \text {; } \\
\text { significância } \\
\text { estatística }\end{array}$ \\
\hline$\alpha 2+\alpha 3$ & $\begin{array}{l}\text { Reversão dos componentes } \\
\text { transitórios nos lucros }\end{array}$ & $\begin{array}{l}\text { Efeito completo em } \\
\text { variações negativas nas } \\
\text { emissoras de ADR }\end{array}$ & $\begin{array}{l}\text { Associação } \\
\text { negativa indicando } \\
\text { reversão }\end{array}$ \\
\hline$\alpha 6$ & $\begin{array}{l}\text { Diferenciação decorrente } \\
\text { da condição de listagem } \\
\text { da firma }\end{array}$ & $\begin{array}{l}\text { Variações positivas no lucro } \\
\text { antecedente em empresas } \\
\text { listadas apenas na Bovespa }\end{array}$ & Coeficiente $<0$ \\
\hline$\alpha 2+\alpha 6$ & $\begin{array}{l}\text { Persistência na série } \\
\text { temporal de lucros }\end{array}$ & $\begin{array}{l}\text { Efeito completo para } \\
\text { variações positivas no lucro } \\
\text { em empresas listadas apenas } \\
\text { na Bovespa }\end{array}$ & Coeficiente $<\alpha 2$ \\
\hline$\alpha 7$ & $\begin{array}{l}\text { Diferenciação decorrente } \\
\text { da condição de listagem } \\
\text { da firma }\end{array}$ & $\begin{array}{l}\text { Variações negativas no lucro } \\
\text { antecedente em empresas } \\
\text { listadas apenas na Bovespa }\end{array}$ & $\begin{array}{l}\text { Coeficiente }>0 \text {; } \\
\text { significância } \\
\text { estatística }\end{array}$ \\
\hline $\begin{array}{l}\alpha 2+\alpha 3+ \\
\alpha 6+\alpha 7\end{array}$ & $\begin{array}{l}\text { Reversão dos componentes } \\
\text { transitórios nos lucros }\end{array}$ & $\begin{array}{l}\text { Efeito completo para } \\
\text { variações negativas no lucro } \\
\text { em empresas listadas apenas } \\
\text { na Bovespa }\end{array}$ & $\begin{array}{l}\text { Coeficiente } \\
>(\alpha 2+\alpha 3)\end{array}$ \\
\hline
\end{tabular}

Fonte: Elaborado pelos autores.

O modelo i será aplicado aos conceitos de lucro líquido, de lucro operacional e de lucro abrangente, o qual foi calculado na forma da seguinte equação

3 No teste referente aos padrões contábeis, somente se aplicará o modelo i no conceito de lucro líquido, com a variável diferenciadora do tipo de sistema contábil assumindo o valor I para os relatórios publicados segundo as práticas contábeis adotadas no Brasil (PCAB) e zero para os elaborados segundo os US Generally Accepted Accounting Principles (USGAAP). 
$L A b_{t}=P L_{t}-P L_{t-\mathrm{I}}+D_{t}-I_{t}$

Onde:

$L A b_{t}=$ Lucro Abrangente (comprehensive income) em t;

$P L=$ Patrimômio Líquido;

$D_{t}=$ Dividendos declarados no período t;

$I_{t}=$ Integralização de capital próprio em $\mathrm{t}$.

Já o segundo modelo busca mostrar a existência de conservadorismo condicional no caso de haver correlação positiva entre fluxos de caixa de sinal negativo e as apropriações contábeis correspondentes; isso indicaria que, na presença de fluxos de caixa negativos, os gestores antecipam perdas prováveis no futuro, sugeridas pelo comportamento contemporâneo. Ao contrário, com fluxos de caixa positivos atuais, não se antecipam ganhos prováveis no futuro, o que implicaria coeficientes negativos entre apropriações contábeis e fluxos de caixa.

\section{MODELO 2}

AS SOCIAÇÃO ENTRE APROPRIAÇÕES

CONTÁBEIS E FLUXOS DE CAIXA

$\begin{aligned} A C_{t}= & \beta_{\circ}+\beta_{\mathrm{I}} D F C O_{t}+\beta_{2} F C O_{t}+\beta_{3} D F C O_{t}^{*} F C O_{t}+ \\ & \beta_{4} D G C+\beta_{5} D G C^{*} D F C O_{t}+\beta_{6} D G C^{*} F C O_{t}+ \\ & \beta_{7} D G C^{*} D F C O_{t} * F C O_{t}+v_{t} \\ \text { Onde: } & \\ A C_{t}= & \text { Apropriações Contábeis no período } t ; \\ F C O_{t}= & \text { Fluxo de Caixa Operacional no período t; } \\ D F C O_{t}= & \text { Variável binária: I para fluxos de caixa negativos e o para } \\ & \text { fluxos de caixa positivos; } \\ D F C O_{t}^{*} F C O_{t}= & \text { Variável de interação para valores negativos de FCO; } \\ D G C= & \text { Variável binária assumindo I para firmas comuns listadas na } \\ & \text { BOVESPA e o para firmas que emitiram ADR; } \\ D G C * D F C O_{t} * F C O_{t}= & \text { Variável de interação para valores referentes às } \\ & \text { firmas listadas na BOVESPA; } \\ D G C^{*} D F C O_{t} ; D G C^{*} F C O_{t}= & \text { Variáveis captadoras de impactos no intercepto do modelo; } \\ \beta_{\mathrm{I}} \text { a } \beta_{7}= & \text { Coeficientes do modelo; } \\ v_{t}= & \text { Termo de erro do modelo; }\end{aligned}$

Fonte: Ball e Shivakumar (2005).

O comportamento esperado dos coeficientes relativos ao modelo 2 é resumido no Quadro 2, em que a associação negativa capta os efeitos de apropriações contábeis feitas com o intuito de compensar fluxos de caixa não realizados, e a associação positiva aponta que foi efetuada antecipação de resultados futuros; 
considera-se que apenas a complementação de fluxos negativos tem conteúdo informacional eficiente. Também aqui se especificam parâmetros que indicam incrementos decorrentes da mudança de natureza dos sinais ou do estado das firmas segundo seu grupo de listagem.

\section{QUADRO 2}

\section{DESCRIÇÃO DOS PARÂMETROS DO MODELO 2}

\begin{tabular}{|c|c|c|c|}
\hline PARÂMETRO & ASSOCIAÇÃO ENTRE VARIÁVEIS & $\begin{array}{l}\text { ESTADO DA VARIÁVEL } \\
\text { INDEPENDENTE }\end{array}$ & $\begin{array}{l}\text { RESULTADO } \\
\text { ESPERADO }\end{array}$ \\
\hline$\beta 2$ & $\begin{array}{l}\text { Compensação do fluxo por } \\
\text { meio de apropriações contábeis }\end{array}$ & $\begin{array}{l}\text { Fluxos de caixa positivos } \\
\text { nas emissoras de ADR }\end{array}$ & $\begin{array}{l}\text { Associação } \\
\text { negativa }\end{array}$ \\
\hline$\beta 3$ & $\begin{array}{l}\text { Incremento devido à condição } \\
\text { negativa do fluxo de caixa }\end{array}$ & $\begin{array}{l}\text { Fluxos de caixa negativos } \\
\text { nas emissoras de ADR }\end{array}$ & $\begin{array}{l}\text { Coeficiente > 0; } \\
\text { significância } \\
\text { estatística }\end{array}$ \\
\hline$\beta 2+\beta 3$ & $\begin{array}{l}\text { Antecipação de perdas por } \\
\text { meio de apropriações contábeis }\end{array}$ & $\begin{array}{l}\text { Efeito para fluxos negativos } \\
\text { nas emissoras de ADR }\end{array}$ & $\begin{array}{l}\text { Associação } \\
\text { positiva }\end{array}$ \\
\hline$\beta 6$ & $\begin{array}{l}\text { Incremento devido à condição } \\
\text { de listagem da firma }\end{array}$ & $\begin{array}{l}\text { Fluxos de caixa positivos em } \\
\text { empresas listadas apenas } \\
\text { na Bovespa }\end{array}$ & Coeficiente $>0$ \\
\hline$\beta 2+\beta 6$ & $\begin{array}{l}\text { Compensação do fluxo por } \\
\text { meio de apropriações contábeis }\end{array}$ & $\begin{array}{l}\text { Efeito para fluxos positivos } \\
\text { em empresas listadas } \\
\text { apenas na Bovespa }\end{array}$ & $\begin{array}{l}\text { Coeficiente } \\
>\beta 2\end{array}$ \\
\hline$\beta 7$ & $\begin{array}{l}\text { Incremento devido à condição } \\
\text { de listagem da firma }\end{array}$ & $\begin{array}{l}\text { Fluxos de caixa negativos } \\
\text { em empresas listadas } \\
\text { apenas na Bovespa }\end{array}$ & $\begin{array}{l}\text { Coeficiente }<0 \text {; } \\
\text { significância } \\
\text { estatística }\end{array}$ \\
\hline $\begin{array}{l}\beta 2+\beta 3+ \\
\beta 6+\beta 7\end{array}$ & $\begin{array}{l}\text { Antecipação de perdas por } \\
\text { meio de apropriações contábeis }\end{array}$ & $\begin{array}{l}\text { Efeito para fluxos negativos } \\
\text { em empresas listadas } \\
\text { apenas na Bovespa }\end{array}$ & $\begin{array}{l}\text { Coeficiente } \\
<(\beta 2+\beta 3)\end{array}$ \\
\hline
\end{tabular}

Fonte: Elaborado pelos autores.

As variáveis "fluxo de caixa" e "apropriações contábeis" foram calculadas na forma das equações seguintes; aplica-se o modelo 2 para o conceito de apropriações contábeis, considerando apenas ajustes pelo regime de competência em contas do capital circulante e alternativamente levando em conta ajustes nas rubricas de longo prazo (provisões e ativos diferidos), com a designação genérica de ativos em circulação. O cálculo descrito é necessário, uma vez que a publicação da demonstração do fluxo de caixa não é legalmente requerida no Brasil4.

4 O modelo 2 não se aplica aos testes sobre padrões contábeis, pela indisponibilidade de dados em USGAAP. 
$F C O_{t}=L A J I R_{t}-D_{t}-R \tilde{N}_{t}-I D_{t}-\Delta C G O_{t}$

$A C_{t}=\Delta C G O_{t}-D_{t}$

Onde:

$\mathrm{FCO}_{t}=$ Fluxo de Caixa Operacional em $\mathrm{t}$;

$L A J I R_{t}=$ Lucro antes do Resultado Financeiro e dos Impostos Diretos em t;

$D_{t}=$ Depreciação em t;

$R \widetilde{N}_{t}=$ Resultado não Operacional em t;

$I D_{t}=$ Impostos Diretos em t;

$\triangle C G O_{t}=$ Variação do Capital de Giro Operacional em t;

$A C_{t}=$ Apropriações Contábeis (accruals) em t.

A amostra considerada para os testes utilizou toda a população-alvo: companhias de capital aberto com informações no banco de dados da Economática ${ }^{\circledR}$. Ademais, todos os dados foram escalados pelo ativo total do período anterior. As amostras finais tiveram a composição expressa na Tabela I, somando 33I firmas, abrangendo o período de $1993 / 2005$.

A disponibilidade de dados contábeis verificáveis nos bancos de informações dá uma primeira medida da existência de demanda por informações públicas, uma vez que apenas cerca de $40 \%$ das companhias dispõem de séries completas de dados para os 13 anos pesquisados na Economática ${ }^{\circledR}$; por essa razão, os modelos foram processados para a amostra final, por meio de dados em painel desbalanceado.

\section{TABELA I}

QUANTIDADE DE CASOS NAS AMOSTRAS

\begin{tabular}{lcccc}
\hline \multirow{2}{*}{ SEGMENTOS } & \multicolumn{2}{c}{ POPULAÇÃO-ALVO } & \multicolumn{2}{c}{ AMOSTRA FINAL } \\
\cline { 2 - 5 } & TOTAL & COM EXCLUSÃO5 & MODELO 1 & MODELO 2 \\
\hline Períodos & $1993 / 2005$ & $1993 / 2005$ & $1999 / 2005$ & $1999 / 2005$ \\
\hline Negociação Bovespa & 297 & 272 & 275 & 259 \\
\hline Emissora ADR & 34 & 28 & 34 & 28 \\
\hline Total & 331 & 300 & 309 & 287 \\
\hline
\end{tabular}

Fonte: Elaborada pelos autores.

Foram excluídos os setores financeiro, de seguros e de fundos para as estimativas do modelo 2, pela diferença no tratamento das apropriações contábeis nesses setores. 
Considerando que a adesão de companhias aos níveis de listagem em bolsas estrangeiras tem maior relevância a partir da atual década e que os dados se apresentam mais completos nos períodos mais recentes, elegeram-se para processamento dos modelos os períodos a partir de I999.

Para os testes da segunda hipótese apresentada, foram utilizados dados referentes aos lucros líquidos e ativos totais apurados nos dois sistemas contábeis de 30 empresas emissoras de ADR, envolvendo o período de 200 I a 2005, disponíveis no Formulário 20-F da SEC. Como 23 das empresas relataram os resultados em dólares, utilizou-se tal moeda para as regressões, optando-se por converter os valores em reais das outras 7 pela taxa de câmbio média de cada ano; os valores finais utilizados nas regressões foram as variações de lucros escaladas pelo ativo total (modelo I).

Para estimar os coeficientes de associação dos dois modelos, utilizou-se análise de dados em painel. Foi usado o método que combina todos os dados em corte transversal e em séries temporais para estimar os modelos utilizando mínimos quadrados ordinários. Esse método é considerado adequado quando a amostra é composta de firmas diferentes (GUJARATI, 2006).

Ademais, foi testada a influência de variáveis não observáveis, seja por efeitos fixos, seja por efeitos aleatórios, usando-se para a análise final a relação estatística mais adequada, consoante os resultados dos testes apropriados de BreuschPagan, Chow e Hausman (SILVA; CRUZ JR., 2004), apurados por meio do uso do software Stata ${ }^{\circledR}$ para os testes ora relatados.

O caráter hipotético-dedutivo da pesquisa se evidencia, pois as hipóteses apresentadas serão testadas estatisticamente em regressões englobando dados globais, para deduzir sobre o comportamento individualizado dos gestores de empresas consideradas na amostra; adota-se, ainda, uma abordagem metodológica positivista, em que o conceito de conservadorismo condicional será testado empiricamente no âmbito das companhias abertas brasileiras.

\section{ANÁLISE dOS RESULTAdOS}

A Tabela 2 apresenta a seleção do método de dados em painel mais apropriado, segundo os resultados dos testes específicos anteriormente comentados. Os testes demonstraram que, para todos os modelos, existem efeitos de variáveis não observáveis, sendo utilizados métodos que reduzem as questões de endogenia presentes nos modelos processados.

Os coeficientes de determinação das regressões que, do ponto de vista da aderência dos dados, se mostram estatisticamente diferentes de zero assumem, todavia, níveis modestos, bem abaixo daqueles encontrados em idêntico estudo realizado na Inglaterra (BALL; SHIVAKUMAR, 2005); o modelo dos componen- 
tes transitórios nos lucros relativo à comparação dos sistemas contábeis, entretanto, apresenta maiores níveis que os encontrados no estudo internacional citado.

\section{TABELA 2}

\section{MEDIDAS DE AJUSTE ECONOMÉTRICO}

\begin{tabular}{lcc}
\hline MODELO & R² AJUSTADO & MÉTODO APLICADO \\
\hline Componentes transitórios no lucro & & \\
\hline Lucro líquido & 0,02 & MQO - pooled \\
\hline Lucro operacional & 0,04 & Efeitos fixos \\
\hline Lucro abrangente & 0,00 & MQO - pooled \\
\hline PCAB versus USGAAP (lucro líquido) & 0,35 & Efeitos fixos \\
\hline Associação entre apropriações contábeis com fluxos de caixa & \\
\hline Variações no capital de giro & 0,09 & Efeitos fixos \\
\hline Variações nos ativos em circulação & 0,03 & Efeitos fixos \\
\hline
\end{tabular}

Fonte: Elaborada pelos autores.

Quanto aos pressupostos de consistência e eficiência das regressões, os testes garantem ausência de autocorrelação serial, além de que o processamento foi realizado com correção robusta de White, garantindo controle dos problemas de heterocedasticidade; a normalidade dos resíduos pode ser assumida, já que, pelo tamanho da amostra, se garante pelo teorema do limite central que sua distribuição tenderá à normalidade.

\section{TABELA 3}

MODELO DE COMPONENTES TRANSITÓRIOS NOS LUCROS

\begin{tabular}{ccccccc}
\hline \multirow{2}{*}{ COEFICIENTE } & \multicolumn{2}{c}{ LUCRO LÍQUIDO } & \multicolumn{2}{c}{ LUCRO OPERACIONAL } & \multicolumn{2}{c}{ LUCRO ABRANGENTE } \\
\cline { 2 - 7 } & ESTATÍSTICA & P-VALUE & ESTATÍSTICA & P-VALUE & ESTATÍSTICA & P-VALUE \\
\hline$\alpha 0$ & $-0,04$ & 0,05 & $-0,00$ & 0,99 & $-0,43$ & 0,20 \\
\hline$\alpha 1$ & 0,00 & 0,97 & $-0,01$ & 0,48 & $-0,08$ & 0,66 \\
\hline$\alpha 2$ & $-0,15$ & 0,69 & $-0,24$ & 0,19 & $-0,16$ & 0,30 \\
\hline$\alpha 3$ & $-0,32$ & 0,38 & $-0,10$ & 0,74 & $-0,15$ & 0,75 \\
\hline
\end{tabular}




\section{TABELA 3 (CONTINUAÇÃO)}

\section{MODELO DE COMPONENTES TRANSITÓRIOS NOS LUCROS}

\begin{tabular}{lcccccc}
\hline \multirow{2}{*}{ COEFICIENTE } & \multicolumn{2}{c}{ LUCRO LÍQUIDO } & \multicolumn{2}{c}{ LUCRO OPERACIONAL } & \multicolumn{2}{c}{ LUCRO ABRANGENTE } \\
\cline { 2 - 7 } & ESTATISTICA & P-VALUE & ESTATISTICA & P-VALUE & ESTATISTICA & P-VALUE \\
\hline$\alpha 4$ & 0,00 & 0,89 & Excluído por multicolinearidade & 0,35 & 0,46 \\
$\alpha 5$ & $-0,00$ & 0,94 & $-0,03$ & 0,36 & $-0,04$ & 0,91 \\
\hline$\alpha 6$ & 0,13 & 0,74 & $-0,21$ & 0,46 & 0,14 & 0,35 \\
\hline$\alpha 7$ & $-0,57$ & 0,62 & 0,04 & 0,92 & 0,17 & 0,73 \\
\hline
\end{tabular}

Fonte: Elaborada pelos autores.

Nas tabelas 3 e 4, apresentam-se os coeficientes das regressões processadas e a probabilidade de que eles sejam estatisticamente iguais a zero ( $p$-value) para os diversos conceitos de lucro e de apropriações contábeis considerados; adota-se, na análise efetuada na sequência, que o nível de significância para aceitação da hipótese é de $5 \%$.

\section{TABELA 4}

MODELO DE ASSOCIAÇÃO ENTRE APROPRIAÇÕES CONTÁBEIS E FLUXOS DE CAIXA

\begin{tabular}{lcccc}
\hline \multirow{2}{*}{ COEFICIENTE } & \multicolumn{2}{c}{ VARIAÇ̃̃ES NO } & \multicolumn{2}{c}{ VARIAÇÕES NOS } \\
& CAPITAL DE GIRO & \multicolumn{2}{c}{ ATIVOS EM CIRCULAÇÃO } \\
\cline { 2 - 5 } & ESTATISTICA & P-VALUE & ESTATÍSTICA & P-VALUE \\
\hline$\beta 0$ & $-0,05$ & 0,00 & $-0,06$ & 0,00 \\
\hline$\beta 1$ & 0,05 & 0,27 & 0,02 & 0,48 \\
\hline$\beta 2$ & $-0,61$ & 0,00 & $-0,64$ & 0,00 \\
\hline$\beta 3$ & 0,20 & 0,44 & $-0,34$ & 0,32 \\
\hline$\beta 4$ & & Excluído por multicolinearidade & \\
\hline$\beta 5$ & 0,09 & 0,04 & 0,21 & 0,00 \\
\hline$\beta 6$ & 0,61 & 0,00 & 0,63 & 0,00 \\
\hline$\beta 7$ & $-0,20$ & 0,44 & 0,34 & 0,33 \\
\hline
\end{tabular}

Fonte: Elaborada pelos autores. 
As inferências relativas ao teste da hipótese levantada na pesquisa serão efetuadas com base nos comportamentos esperados dos coeficientes, na forma definida nos quadros 2 e 3; no que diz respeito às conclusões quanto às diferenças entre valores negativos e positivos e entre os dois blocos de empresas, serão avaliados os parâmetros referentes às variáveis de interação em tais aspectos. Quanto à constatação relativa à antecipação assimétrica de perdas e ao conservadorismo condicional, apreciar-se-ão os efeitos da adição dos parâmetros para cada um dos grupos sob análise. Tais dados estão expostos nas tabelas 5 e 6 .

$\mathrm{Na}$ Tabela 5, analisam-se os efeitos relevantes dos coeficientes como explicadores da presença de antecipação assimétrica de perdas, que caracterizam o atributo do conservadorismo condicional. As constatações de tal análise podem ser resumidas nos seguintes pontos:

I. As empresas que não emitiram ADR praticam antecipação assimétrica de perdas econômicas em maior nível que o outro grupo considerado:

a) No conceito de lucro líquido, o somatório dos coeficientes $(\alpha 2+\alpha 3+\alpha 6$ $+\alpha 7)$ indicativos de persistência/reversão de componentes do lucro na presença de variações negativas do lucro antecedente tem valor negativo maior que o do outro segmento [ $\left.\alpha_{2}+\alpha_{3}\right]$;

b) A situação se repete para o conceito de lucro operacional, porém em valores absolutos menores; o significado é que se evidencia registro de perdas econômicas nas contas não operacionais do lucro, dando a entender que este grupo de firmas utiliza as contas não operacionais para reduzir ainda mais seus resultados na presença de variações negativas do lucro;

c) Efeito diferenciado é percebido no conceito de lucro abrangente (o somatório dos coeficientes é igual a zero); provavelmente a persistência de componentes do lucro em termos de variação do patrimônio líquido se deva ao instituto da reavaliação de ativos contabilizada diretamente no PL, prática disseminada na realidade brasileira.

2. As companhias participantes do programa de listagem no mercado americano aparentam, pelo sinal de reversão dos coeficientes respectivos $\left(\alpha 2+\alpha_{3}\right.$ com sinal negativo), adotar a antecipação assimétrica de perdas econômicas, também com menor ênfase no conceito de lucro abrangente.

3. Não é captada diferença estatisticamente significante no comportamento dos dois grupos de empresas, em todos os conceitos de lucro, no que toca à reversão esperada de componentes transitórios na ocorrência de variações negativas do lucro (coeficiente $\alpha 7$ com $p$-value $>0,05$ ). 
4. A persistência dos componentes do lucro em caso de variações positivas nos lucros antecedentes (coeficiente $\alpha 6$ com $p$-value > 0,05) também se apresenta semelhante nos dois grupos de firmas considerados.

5. Também não se confirmam indícios de apropriação assimétrica de perdas econômicas, já que os coeficientes $\alpha_{3}$ e $\alpha 7$, referentes às variáveis de interação diferenciadoras do sinal nas variações do lucro antecedente, não exibem significância estatística nos três conceitos de lucro; como tais coeficientes portam sinal negativo, infere-se que são efetuados registros antecipados tanto de perdas quanto de lucros econômicos nos dois grupos de firmas considerados.

6. Enfim, a reversão de componentes transitórios nas vezes em que a variação do lucro antecedente é positiva (coeficientes $\alpha 2$ e $\alpha 6$ sem significância estatística) apresenta-se em valores relevantes nos três conceitos de lucro; isso implica comportamento errático e não esperado no modelo tratado, o qual espera coeficientes próximos de zero, o que significa a não antecipação de ganhos em tal situação.

A apreciação do grau de antecipação do registro de perdas/ganhos econômicos, estimado pelo modelo de componentes transitórios nos lucros, não induz à rejeição completa da primeira hipótese nula da pesquisa $\left(\mathrm{H}_{\circ \mathrm{A}}\right)$, na medida em que se constata a presença de antecipação de perdas econômicas pelas companhias emissoras de ADR; contudo, outros fatores não autorizam a rejeição dessa hipótese:

a) Os dois grupos de companhias apresentam reversão de componentes de forma similar;

b) Também se detecta antecipação de ganhos pelos dois grupos de empresas;

c) Os baixos coeficientes de determinação das regressões, embora estatisticamente significantes, não suportam inferências econômicas mais robustas, denotando uma relação errática na série de lucros das empresas amostradas. 


\section{TABELA 5}

ANÁLISE DA EXISTÊNCIA DE ANTECIPAÇÃO

TEMPESTIVA ASSIMÉTRICA

\begin{tabular}{|c|c|c|c|c|c|c|}
\hline \multirow{2}{*}{ PARÂMETRO } & \multicolumn{2}{|c|}{ LUCRO LÍQUIDO } & \multicolumn{2}{|c|}{ LUCRO OPERACIONAL } & \multicolumn{2}{|c|}{ LUCRO ABRANGENTE } \\
\hline & COEFICIENTE & ANÁLISE & COEFICIENTE & ANÁLISE & COEFICIENTE & ANÁLISE \\
\hline$\alpha 2$ & $-0,15$ & $\begin{array}{c}\text { Não } \\
\text { significante }\end{array}$ & $-0,24$ & $\begin{array}{c}\text { Não } \\
\text { significante }\end{array}$ & $-0,16$ & $\begin{array}{c}\text { Não } \\
\text { significante }\end{array}$ \\
\hline$\alpha 3$ & $-0,32$ & $\begin{array}{c}\text { Não } \\
\text { significante }\end{array}$ & $-0,10$ & $\begin{array}{c}\text { Não } \\
\text { significante }\end{array}$ & $-0,15$ & $\begin{array}{c}\text { Não } \\
\text { significante }\end{array}$ \\
\hline$\alpha 2+\alpha 3$ & $-0,47$ & $\begin{array}{c}\text { Efeito } \\
\text { esperado }\end{array}$ & $-0,34$ & $\begin{array}{c}\text { Efeito } \\
\text { esperado }\end{array}$ & $-0,31$ & $\begin{array}{c}\text { Efeito } \\
\text { esperado }\end{array}$ \\
\hline$\alpha 6$ & 0,13 & $\begin{array}{c}\text { Não } \\
\text { significante }\end{array}$ & $-0,21$ & $\begin{array}{c}\text { Não } \\
\text { significante }\end{array}$ & 0,14 & $\begin{array}{c}\text { Não } \\
\text { significante }\end{array}$ \\
\hline$\alpha 2+\alpha 6$ & $-0,02$ & $\begin{array}{c}\text { Efeito } \\
\text { esperado }\end{array}$ & $-0,45$ & $\begin{array}{l}\text { Efeito } \\
\text { inverso }\end{array}$ & $-0,02$ & $\begin{array}{c}\text { Efeito } \\
\text { esperado }\end{array}$ \\
\hline$\alpha 7$ & $-0,57$ & $\begin{array}{c}\text { Não } \\
\text { significante }\end{array}$ & 0,04 & $\begin{array}{c}\text { Não } \\
\text { significante }\end{array}$ & 0,17 & $\begin{array}{c}\text { Não } \\
\text { significante }\end{array}$ \\
\hline $\begin{array}{l}\alpha 2+\alpha 3+\alpha 6 \\
+\alpha 7\end{array}$ & $-0,91$ & $\begin{array}{l}\text { Efeito } \\
\text { inverso }\end{array}$ & $-0,51$ & $\begin{array}{l}\text { Efeito } \\
\text { inverso }\end{array}$ & 0,00 & $\begin{array}{c}\text { Efeito } \\
\text { esperado }\end{array}$ \\
\hline
\end{tabular}

Fonte: Elaborada pelos autores.

Esse modelo, entretanto, não atenta para o fato de que o conteúdo do lucro engloba movimentos de fluxo de caixa e de estrita apropriação contábil, valendo dizer que os resultados podem estar sendo derivados de acréscimos e decréscimos ocorridos no lucro decorrentes tão somente de alterações no nível de atividade das firmas sob exame.

Assim, busca-se confirmar as inferências do primeiro modelo pela análise estrita da correlação entre as apropriações contábeis e os fluxos de caixa contemporâneos, em virtude da convicção de que o registro de eventuais perdas econômicas se dará pelo instituto das apropriações contábeis; as correlações negativas ocorrerão por conta do regime de competência, enquanto as positivas serão devidas a registros econômicos antecipados.

A Tabela 6 resume os achados da análise desse segundo modelo, valendo comentar as seguintes inferências, baseadas no comportamento dos parâmetros estimados: 
a) A correlação entre apropriações contábeis e fluxos de caixa, quando estes são positivos (coeficiente $\beta 2$ negativo), relativa às firmas emissoras de ADR contém informação estatisticamente significante e indica compensações decorrentes do regime de competência;

b) Já as empresas listadas apenas na Bovespa (coeficiente $\beta 2+\beta 6$ nulo) parecem antecipar ganhos, o que caracterizaria comportamento oportunista dos gestores; ressalte-se que a diferença entre as empresas nesse aspecto é estatisticamente significante (coeficiente $\beta 6$ ); como o sinal deste coeficiente é positivo, não se preveem compensações derivadas do regime de competência para as empresas sob comentário;

c) Os coeficientes das variáveis de interação ( $\beta_{3}$ e $\beta 7$ ), diferenciadoras das observações com fluxo de caixa positivo ou negativo, não apresentaram significância estatística, indicando que não há divergência de comportamento para a efetivação de apropriações contábeis nas ocorrências de fluxos de caixa positivos ou negativos para o conjunto das empresas amostradas;

d) As empresas que não emitiram ADR parecem antecipar mais o registro de perdas econômicas no conceito amplo de capital de giro (coeficiente $\beta 7$ positivo) que no conceito de curto prazo, já que o coeficiente apresenta-se negativo;

e) Contudo, é bom frisar que o registro antecipado de ganhos econômicos (coeficiente $\beta 6$ positivo) também é exercido por esse grupo de empresas;

f) Tais firmas, do ponto de vista informacional, demonstram uma correlação de caráter errático ou determinado por fenômenos não observáveis no modelo, uma vez que o somatório dos coeficientes associados à relação entre as apropriações contábeis e os fluxos de caixa são estatisticamente nulos $(\beta 2+$ $\beta 6 ; \beta 2+\beta 3+\beta 6+\beta 7)$

g) Destaque-se que a divergência entre os dois grupos de empresas se dá no que tange à função das apropriações contábeis, já que as empresas emissoras de ADR, por sua vez, parecem utilizar as apropriações contábeis preponderantemente para as funções associadas ao regime de competência contábil (coeficientes $\beta_{2}$ e $\beta 2+\beta_{3}$ negativos). 


\section{TABELA 6}

ANÁLISE DA EXISTÊNCIA DE CONSERVADORISMO CONDICIONAL

\begin{tabular}{|c|c|c|c|c|}
\hline $\begin{array}{l}\text { PARÂMETROS } \\
\text { DE INTERESSE }\end{array}$ & $\begin{array}{l}\text { CAPITAL } \\
\text { DE GIRO }\end{array}$ & $\begin{array}{l}\text { ATIVOS EM } \\
\text { CIRCULAÇÃO }\end{array}$ & ANÁLISE & COMENTÁRIOS \\
\hline$\beta 2$ & $-0,61$ & $-0,64$ & Significante & $\begin{array}{l}\text { Fluxos de caixa positivos de empresas } \\
\text { emissoras são apenas compensados. }\end{array}$ \\
\hline$\beta 3$ & 0,20 & $-0,34$ & $\begin{array}{l}\text { Não } \\
\text { significante }\end{array}$ & $\begin{array}{l}\text { Não há diferença de comportamento } \\
\text { para fluxos positivos e negativos para } \\
\text { empresas emissoras. }\end{array}$ \\
\hline$\beta 2+\beta 3$ & $-0,41$ & $-0,98$ & - & $\begin{array}{l}\text { Fluxos de caixa negativos de empresas } \\
\text { emissoras são apenas compensados. }\end{array}$ \\
\hline$\beta 6$ & 0,61 & 0,63 & Significante & $\begin{array}{l}\text { Há diferença entre emissoras de ADR e } \\
\text { não emissoras com fluxos positivos; estas } \\
\text { antecipam ganhos. }\end{array}$ \\
\hline$\beta 2+\beta 6$ & 0,00 & $-0,01$ & - & $\begin{array}{l}\text { Empresas não emissoras antecipam } \\
\text { ganhos na ocorrência de fluxos positivos. }\end{array}$ \\
\hline$\beta 7$ & $-0,20$ & 0,34 & $\begin{array}{l}\text { Não } \\
\text { significante }\end{array}$ & $\begin{array}{l}\text { Não há diferenciação entre os grupos de } \\
\text { empresas com fluxos de caixa negativos. }\end{array}$ \\
\hline $\begin{array}{l}\beta 2+\beta 3+ \\
\beta 6+\beta 7\end{array}$ & 0,00 & $-0,01$ & - & $\begin{array}{l}\text { Empresas não emissoras antecipam } \\
\text { perdas na ocorrência de fluxos negativos. }\end{array}$ \\
\hline
\end{tabular}

Fonte: Elaborada pelos autores.

Pela apreciação do modelo 2, não se pode rejeitar a hipótese proposta $\left(\mathrm{H}_{\circ \mathrm{A}}\right)$, dado que os resultados da regressão não autorizam a inferência de antecipação assimétrica de perdas econômicas; também não há indicação estatística de que haja diferenças na utilização dessa prática contábil entre os segmentos de companhias abertas listadas no mercado americano e de empresas listadas apenas no mercado interno brasileiro; a ressalva quanto aos baixos coeficientes de determinação nas regressões permanece digna de nota.

Vale destacar que, no caso de fluxos de caixa positivos, as firmas não listadas no exterior apresentam antecipação assimétrica de ganhos econômicos, com significância estatística, o que caracterizaria práticas de gerenciamento de resultados nesse segmento. 


\section{TABELA 7}

ANÁLISE DE ANTECIPAÇÃO ASSIMÉTRICA

NOS SISTEMAS CONTÁBEIS

\begin{tabular}{|c|c|c|c|}
\hline \multirow{2}{*}{ COEFICIENTE } & \multicolumn{2}{|c|}{ USGAAP/PCAB } & \multirow{2}{*}{ ANÁLISE DOS PARÂMETROS DE INTERESSE } \\
\hline & ESTATÍSTICA & P-value & \\
\hline$\alpha 0$ & 1,87 & 0,00 & \multirow{2}{*}{ Sem comentários } \\
\hline$\alpha 1$ & 0,00 & 0,98 & \\
\hline$\alpha 2$ & $-2,26$ & 0,00 & $\begin{array}{l}\text { Há reversão nos componentes transitórios nos } \\
\text { lucros }\end{array}$ \\
\hline$\alpha 3$ & 3,41 & 0,00 & $\begin{array}{l}\text { Diferente comportamento entre os sinais das } \\
\text { variações de lucro }\end{array}$ \\
\hline$\alpha 4$ & \multicolumn{2}{|c|}{ Excluído - multicolinearidade } & \multirow{2}{*}{ Sem comentários } \\
\hline$\alpha 5$ & 0,13 & 0,49 & \\
\hline$\alpha 6$ & 0,30 & 0,00 & Diferente comportamento em USGAAP e PCAB \\
\hline$\alpha 7$ & $-0,42$ & 0,00 & Diferente comportamento em USGAAP e PCAB \\
\hline$\alpha 2+\alpha 3$ & 1,15 & - & $\begin{array}{l}\text { Há persistência nos componentes transitórios } \\
\text { nos lucros }\end{array}$ \\
\hline$\alpha 2+\alpha 6$ & $-1,96$ & - & $\begin{array}{l}\text { Há reversão nos componentes transitórios nos } \\
\text { lucros }\end{array}$ \\
\hline $\begin{array}{l}\alpha 2+\alpha 3+\alpha 6 \\
+\alpha 7\end{array}$ & 1,03 & - & $\begin{array}{l}\text { Há persistência nos componentes transitórios } \\
\text { nos lucros }\end{array}$ \\
\hline
\end{tabular}

Fonte: Elaborada pelos autores.

Os resultados referentes à segunda hipótese testada $\left(\mathrm{H}_{\mathrm{OB}}\right)$ são exibidos na Tabela 7 , donde se pode concluir que a hipótese pode ser rejeitada, pelo fato de que os coeficientes das variáveis binárias de interação $(\alpha 6+\alpha 7)$ são estatisticamente significantes. É interessante ainda tecer os seguintes comentários sobre os resultados:

a) Os resultados confirmam que não se podem atribuir níveis de conservadorismo nos lucros reportados por empresas cross-listed, independentemente do sistema contábil adotado; 
b) Também se detecta a reversão de componentes transitórios nos lucros, nas duas estruturas normativas, na presença de variações positivas nos lucros antecedentes, denotando presença de gerenciamento de resultados;

c) As diferenças indicam grau de conservadorismo menos acentuado nos resultados reportados, segundos as normas denominadas USGAAP.

\section{CONCLUSÕES}

O objeto do estudo é examinar os atributos de qualidade informacional das peças contábeis divulgadas pelas companhias abertas brasileiras emissoras de ADR; foram escolhidas a prática de conservadorismo condicional e a antecipação assimétrica de perdas econômicas como tais atributos.

A premissa da pesquisa é de que a presença desses sinais de qualidade informacional está associada à demanda pelos contratantes da empresa, mormente investidores e acionistas minoritários, por números contábeis públicos que sejam eficientes informacionalmente. Para que tal demanda seja efetiva, é necessária a existência de incentivos econômicos que induzam os gestores a atender a ela.

As hipóteses da pesquisa de que o processo de emissão de ADR por companhias abertas brasileiras não as conduziria à produção de informações contábeis com lucros informacionalmente eficientes não puderam ser rejeitadas, uma vez que os testes indicaram que:

a) As reversões de componentes transitórios nos lucros não ocorrem apenas quando da existência de más notícias para os dois grupos de empresas na amostra;

b) A correlação entre apropriações e fluxos de caixa não revela a utilização da função de antecipação assimétrica de perdas econômicas também para os dois grupos de empresas;

c) A comparação entre balanços elaborados nos dois sistemas contábeis pesquisados, embora apresente diferenças estatisticamente significantes, mostra coeficientes que não conduzem à inferência de prática de conservadorismo condicional.

Em termos contábeis, os achados da pesquisa, mantidas as ressalvas de praxe no que toca à qualidade e quantidade dos dados contábeis disponíveis no Brasil, levam à ilação de que a diferença de princípios contábeis não implica diferenças nos graus de atributos aceitos como indicativos de qualidade nos lucros publicados, qual seja, a antecipação assimétrica de perdas econômicas. 
Do ponto de vista econômico, pode-se concluir que os incentivos referentes à listagem no mercado americano não são suficientes para induzir gestores à adoção de práticas conservadoras de divulgação de resultados, os quais não contêm sinais de que possam ser utilizados com eficiência informacional na monitoração de contratos.

\section{REFERÊENCIAS}

BALL, R. J. Infrastructure requirements for an economically efficient system of public financial reporting and disclosure. In: Brookings-Wharton Papers on Financial Services. Massachusetts: Brookings Institution Press, 200I.

BALL, R. J.; KOTHARI, S. P.; ROBIN, A. The effect of international factors on properties of accounting earnings. Journal of Accounting and Economics, Amsterdam, v. 29, p. I-5I, Feb. 2000.

BALL, R. J.; ROBIN, A.; WU, J. S. Accounting standards, the institutional environment and issuer incentives: effect on timely loss recognition in China. Asia-Pacific Journal of Accounting and Economics, Hong Kong, v. 7, p. 7I-96, Dec. 2000.

Incentive versus standards: properties of accounting income in four East Asian countries. Journal of Accounting and Economics, Amsterdam, v. 36, p. 235-270, Dec. 2003.

BALL, R. J.; SHIVAKUMAR, L. Earnings quality in UK private firms: comparative loss recognition timeliness. Journal of Accounting and Economics, Amsterdam, v. 39, p. 83-128, 2005.

BASU, S. The conservatism principle and the asymmetric timeliness of earnings. Journal of Accounting and Economics, Amsterdam, v. 24, n. I, p. 3-37, 1997.

BLACK, B. S. Strengthening Brazil's securities markets. Stanford Law School, 200I. Disponível em: <http://papers.ssrn.com/paper.taf?abstract_id=247673>. Acesso em: I4 abr. 2006.

BUSHMAN, R. M.; PIOTROSKI, J. D. Financial reporting incentives for conservative accounting: the influence of legal and political institutions. Journal of Accounting and Economics, Amsterdam, v. 42, n. 2, 2006.

BUSHMAN, R. M.; PIOTROSKI, J. D.; SMITH, A. J. What determines corporate transparency? Journal of Accounting Research, Chicago, v. 42, n. 2, May 2004.

COELHO, A. C. Qualidade informacional e conservadorismo nos resultados contábeis publicados no Brasil. 2007. Tese (Doutorado em Contabilidade)-Universidade de São Paulo, São Paulo, 2007. GARCÍA-LARA, J. M.; MORA, A. Balance sheet versus earnings conservatism in Europe. European Accounting Review, London, v. I3, n. 2, p. 26I-292, 2004.

GUJARATI, D. Econometria básica. 4. ed. Rio de Janeiro: Campus, 2006.

HUIJGEN, C; LUBBERINK, M. Earnings conservatism, litigation, and contracting: the case of cross-listed firms. Gronigen, Holland, 2003. Disponível em: <http://papers.ssrn.com/sol3/DisplayAbstractSearch.cfm>. Acesso em: I4 abr. 2006.

IUDÍCIBUS, S. de. Teoria da contabilidade. 7. ed. São Paulo: Atlas, 2004.

LEMES, S.; CARVALHO, L. N.; LOPES, L. C. O. Comparabilidade entre os BRGAAP e os USGAAP: algumas evidências das companhias brasileiras listadas na NYSE. In: ENCONTRO DA ANPAD, 3I., 2007. Rio de Janeiro. Anais... Rio de Janeiro. CD-ROM. 
LEUZ, C.; NANDA, D.; WYSOCKI, P. D. Earnings management and investor protection: an international comparison. Journal of Financial Economics, Rochester, v. 69, p. 505-527, Sept. 2003.

LOPES, A. B.; TUKAMOTO, Y. S. Contribuição ao estudo do "gerenciamento" de resultados: uma comparação entre as companhias abertas brasileiras emissoras de ADRs e não-emissoras de ADRs. Revista de Administração USP, São Paulo, v. 42, n. I, p. 86-96, 2007.

LUBBERINK, M.; HUIJGEN, C. Cross-listing in US markets and conservatism: does type of listing matter? Lancaster, UK, 2005. Disponível em: <http://papers.ssrn.com/sol3/DisplayAbstractSearch. cfm>. Acesso em: I4 abr. 2006.

POPE, P. F.; WALKER, M. International differences in the timeliness, conservatism and classification of earnings. Journal of Accounting Research, Chicago, v. 37, p. 53-87, I999. Supplement.

SANTOS, E. S.; CIA, J. N. S.; CIA, J. C. USGAAP x normas brasileiras: há diferenças significativas no valor do lucro reportado pelas empresas brasileiras com ADRs na Nyse? In: ENCONTRO DA ANPAD, 3I., 2007. Rio de Janeiro. Anais... Rio de Janeiro. CD-ROM.

SANTOS, L. S. R. dos. Conservadorismo contábil e timeliness: evidências empíricas nos demonstrativos contábeis em USGAAP e BRGAAP das empresas brasileiras com ADRS negociadas na Bolsa de Nova Iorque. 2006. Dissertação (Mestrado em Contabilidade)-Fundação Instituto Capixaba de Pesquisa em Contabilidade, Economia e Finanças, Vitória, 2006.

SILVA, O. M. da; CRUZ JR., J. C. Dados em painel: uma análise do modelo estático. In: SANTOS, M. L. dos; VIEIRA, W. da C. (Org.). Métodos quantitativos em economia. Viçosa: Imprensa Universitária, 2004.

WATTS, R. L. Conservatism in accounting. Part I: Explanations and implications. Accounting Horizons, Sarasota, v. I7, n. 3, p. 207-22I, 2003. 